\title{
RESEARCH ON THE IMPLICATIONS OF BUSINESS ENGLISH TEACHING ON BILINGUAL COURSES IN BUSINESS COMMUNICATION
}

\author{
Yang $\mathrm{Xi}^{*}$ \\ Wuhan Business University, Wuhan 430056, China \\ *Corresponding Author Email: 790227783@qq.com
}

This is an open access article distributed under the Creative Commons Attribution License, which permits unrestricted use, distribution, and reproduction in any medium, provided the original work is properly cited.

\section{ARTICLE DETAILS}

\section{Article History:}

Received 28 April 2018

Accepted 29 May 2018

Available online 1 Jun 2018

\section{ABSTRACT}

The "Business Communication" course is a bilingual compulsory course offered by the economic management major, which is a practical skill course derived from life. How to apply the content correctly to practice has always been an important topic. Business English is the foundation of the business communication, and the mature experience of business English teaching provides fruitful experience for business communication bilingual teaching. Based on the analysis of the teaching objectives and teaching modes of business English, this study further summarizes the teaching objectives of the bilingual course of business communication and the precautions in different teaching modes, and to provide ideas for the teaching of this course.

\section{KEYWORDS}

Business communication, business English, teaching objective, teaching mode.

\section{INTRODUCTION}

With the continuous development of China's economy and the widening and deepening of the field of opening up, the demand for high-level foreign-related talents has become more urgent. This kind of high-level talents should be a kind of compound talents. They should be familiar with the basic knowledge of international business profession while being proficient in English. In addition, they should be familiar with international conventions and be good at cross-cultural communication. This puts higher and higher requirements on the teaching of international business communication. Due to the vague cognition of bilingual teaching, the lack of bilingual teachers, the lack of suitable bilingual teaching materials and the uneven level of students, the bilingual teaching effect of business communication is not obvious. Therefore, the bilingual teaching mode of business communication needs to be explored and improved. Business English is the foundation of business communication. The mature experience of business English teaching will inevitably provide fruitful experience for bilingual teaching of business communication. This study first expounds the theoretical basis of the bilingual course of business English and business communication. Then, it analyzes the evolution of the teaching objectives of business English from the perspectives of teachers and students and expounds the characteristics of three mainstream modes of business English teaching, and condenses the mature experience of business English teaching. Finally, the teaching goal setting of the bilingual course of business communication and the precautions in different teaching modes are summarized to provide ideas for the teaching of this course.

\section{THEORIES ON BILINGUAL COURSES IN BUSINESS ENGLISH AND} BUSINESS COMMUNICATION

Based on a study, Business English mainly focuses on communication under the business environment while business communication is to introduce students to the communication skills and norms required in the daily business activities of enterprises, especially in international business activities [1]. According to research, Business English is the foundation of business communication and only by learning business English well can students better understand and master business communication knowledge [2].
In the production and life of modern society, economic relations are continuously close and business activities are increasingly frequent, which makes business-themed communication and negotiation more and more important, and its application fields are more and more extensive. The savvier and more skilled you are in mastering business communication and negotiation skills, the more helpful it will be in achieving professional success in your future business activities for you.

Business communication courses are mainly offered to students who may be engaged in international trade, marketing, financial management, and other international business working fields in the future. The course is to help them master the basic knowledge and principles of business communication, cultivate their interpersonal skills, team communication and team work spirit, which has very strong practicability and operability. Business communication is a professional course combining theory with practice. In real life, its ultimate goal is to achieve win-win results and it involves all aspects of business activities. As a result, the importance of business communication is evident.

\section{MATURE EXPERIENCE OF BUSINESS ENGLISH TEACHING}

\subsection{Objective of business English teaching}

Facing with a variety of teaching choices, diversification of business English teaching management and difference in education background of teachers, teachers' understanding of business English teaching purposes will also be different. The evolution of the teaching objectives of business English is diversified. The goal of business English teaching has evolved from the initial focus on language skills and language application to the emphasis on communicative competence, business knowledge and skills.

\subsubsection{Supply of business English teaching targets from the perspective of teachers}

The first goal of business English teaching is to impart language knowledge. Business English teachers with language background tend to focus on the teaching of language knowledge. They believe that the purpose of business English teaching is to improve the English level of Chinese students, enable them to master two languages, integrate into the society faster and adapt to the needs of the society. 
The second goal of business English teaching is to impart professional business knowledge. The teachers with business background pay special attention to the input of business knowledge. They believe that the purpose of business English teaching is to improve students' professional knowledge of business communication and negotiation while English is an auxiliary tool.

\subsubsection{Requirements of business English teaching targets from the perspective of students}

Many students who have never learned or are learning business English don't really know the requirements of business English teaching. For students who have not yet passed the language proficiency, they may pay more attention to the teaching of language knowledge in business English teaching while for students with a certain language foundation, they should focus more on the study of professional business knowledge [3].

It can be seen that teachers and students inevitably have cognitive ambiguity in business English teaching due to their different education backgrounds and footholds. In fact, the fundamental purpose of business English teaching is to meet the requirements of students. According to a scholar, business English teachers are required to have relevant knowledge and realize the unification of language knowledge and professional business knowledge imparting on the basis of considering the knowledge foundation and learning needs of students [4].

\subsection{The modes of business English teaching}

Business English teaching method or mode is the mainstream of business English teaching research in China. Constructivist teaching theory, network media technical assistance and project drive constitute the main research paradigm of China's business English teaching [5]. Study showed the business English teaching mode mainly consists of teaching methods based on content, demand analysis teaching method and case teaching method [6].

\subsubsection{Content-Based Instruction (CBI)}

Teaching depending on content is a business English teaching mode that integrates language and content organically. The core of CBI is to integrate language learning and the learning of business communication professional knowledge, which acquires language ability through subject teaching rather than simple language learning [7]. Snow believes that "the premise of content-based teaching means that language can only be learned best if it is the carrier, not the object of teaching."

\subsubsection{English for Specific Purposes (ESP)}

ESP mainly emphasizes that the content of business English courses must be related to business English subjects, foreign trade career and business negotiation. Based on the theory of demand analysis, ESP closely combines English language learning with students' future career demands and focuses on cultivating students' language application ability in the work environment [8]. In ESP classes, the English language is not the main content, but something learned in the process of acquiring a completely different knowledge or skills. Under the background of ESP teaching mode, relevant personnel should take two kinds of needs of the teaching objects into full consideration when compiling the teaching outline of business English major and business English teaching materials. The first one is the learner's goal needs, that is, business English should reflect the field, application environment and communication objects that the learner will use in the future; the second one is the learning needs, which includes what business knowledge the learner needs to learn, the reasonable arrangement of the business knowledge structure and effective learning methods, etc.

\subsubsection{Case method of instruction}

The case method of instruction, originated in the 1920s, is a unique casebased teaching model advocated by Harvard Business School. These cases are from real events or situations of business management. In this way, it helps to cultivate students' positive initiative and enables students to actively participate in classroom learning discussions. The case analysis in business English teaching focuses on selecting the typical business communication situation or work task as the core of learning. It will plan and arrange the communication problems, language skills and strategy choices that will be encountered in the business process. A complete simulation project and the corresponding teaching activities are carried out to simulate a complete teaching process whose purposes are to enable students to actively explore the necessary learning materials to complete the task under certain scenario simulations and obtain relevant professional competence through construction of meaning. It helps students exercise the professional application skills needed to complete individual projects in a single project, so that business communication skills can be exercised and gradually improved.

\section{THE IMPLICATIONS OF BUSINESS ENGLISH TEACHING ON BILINGUAL COURSES IN BUSINESS COMMUNICATION}

The mature experience of business English teaching in teaching objectives and teaching modes can provide inspiration for the teaching and research of bilingual courses in business communication. Based on the above analysis of business English teaching, it is found that on the basis of business English teaching mode, the communication skills and norms required by business communication in international business activities can make the bilingual courses of business communication achieve expected results [9].

\subsection{The teaching goal of the combination of professional business and} language knowledge

As for the bilingual courses of business communication, the primary teaching objective is the teaching of professional business knowledge in business communication, while the secondary objective is the teaching of business English. Under the guidance of these teaching goals, the following requirements for teachers and students are put forward.

Teachers should have solid experience in teaching business communication. Combining business communication bilingual teaching target and equipped with knowledge of business English expression as well as teaching skills, teachers should be familiar with the business communication process, type, language style, negotiation strategy, social customs and cultural differences in international business negotiation, other related theory, key points and difficulties and know the theory of business communication. What's more, they should also store abundant cases, film and television information and so on. This course requires much professional skills and theoretical knowledge of business communication than just business English teaching experience.

Students should have basic knowledge of business English. According to the relationship between business English teaching and business communication bilingual courses and teaching objectives, the language ability required by business English is necessity for students. Any relevant theoretical knowledge of business communication should be taught on the basis of business English. Only when students master basic business English can they learn business communication theory more smoothly.

Of course, even if the students have basic business English knowledge, the language level, knowledge reserve and learning ability of the students are different. The teachers should also have a certain understanding of students. On the basis of fully understanding the students' basic level, the course content should be modified appropriately under the guidance of teaching objectives, so that the students can master it effectively.

\subsection{A bilingual course in business communication supported by a} variety of teaching modes

The teaching modes of CBI, ESP and case method in business English teaching are particularly applicable to the bilingual teaching of business communication, but we should pay attention to the requirements and norms of business communication courses.

\subsubsection{Content-Based Instruction (CBI)}

The implementation of CBI teaching in the bilingual course of business communication should pay special attention to the real scene and context. The creation of real situation is the necessary guarantee to improve language and content learning. Teachers should consciously simulate real business scenarios according to communication skills, processes and negotiation style and let the student visually realize the business negotiation skills and negotiation and marketing expertise that they need to master in their simulation training and role-playing. What's more, teaching methods should be diversified while teaching content should be actualized.

\subsubsection{English for Specific Purposes (ESP)}

In the bilingual teaching of business communication, the needs of teaching objects (learning needs and target requirements) should be fully considered. On the one hand, teachers can understand the language, knowledge and learning ability of students according to the existing experience in teaching, questionnaire survey and case interview methods, and have a grasp of students' existing language level, business knowledge 
and skills, cultural background, and analyze their learning motivation and attitude, learning background, learning styles and preferences of teaching methods. Finally, teachers will figure out what knowledge learners need to learn and the depth of the study and make reasonable arrangements of business communication bilingual course target, teaching content, and teach them methods of effective learning to improve the students' ability to read and understand. On the other hand, business communication should reflect the fields, application environment, communication where the learners will use in the future. Reasonable business communication bilingual teaching plans and lectures should be formulated for students' future career planning, work environment, and positions. And it should be aimed at students' practical practice and mastery of skills.

\subsubsection{Case method of instruction}

This method can effectively apply the case teaching method to the bilingual teaching of business communication, and it is not one-sidedly limited to the old cases in the teaching materials. Besides, it strengthens the case analysis mode teaching in the bilingual course of business communication from the textbooks and film and television materials.

Choosing even writing a real case. The selected cases, relevant to students' learning or future work, should be lively and interesting, and belong to a certain business topic and reflect certain cultural information. This will not only arouse the interest of the students but will not make them feel at a loss. In addition, the language of the case should be appropriate for the student, and the length and difficulty should match the student's language level.

The selection of film and television cases. The film "China Partner" and "thirteen days" are especially suitable for the case teaching of business communication bilingual courses. The English business negotiation with ESS in the final scene of "China Partner" is conducive to teaching about the opening of the atmosphere in the business negotiation bilingual course, the deadlock and conflict humor processing, the preparation of professional knowledge related to the negotiation issues, etc. At the same time, "thirteen days" is based on international political business negotiations, whose types of negotiation, use of negotiation strategies such as retreat, informal talks, and the analysis of successful signing of negotiations are important knowledge contents of the bilingual course of business communication.

In addition, case teaching is generally carried out in an open environment. For example, the analysis of the film and television case is not an easy entertainment and there may be many problems in the teaching process. Thus, to achieve good results, teachers must do a good job in organizing the case teaching.

\section{CONCLUSION}

Business communication skills have become increasingly important in business fields, as a result, bilingual courses in business communication have gradually become a significant research topic. Affected by general problems in bilingual teaching, the bilingual teaching effect of business communication has not been ideal. However, business English teaching has formed some mature and effective theory in the setting of teaching objectives and diversification of teaching modes. Therefore, it has certain enlightening significance for the bilingual teaching of business communication. It's believed that the bilingual teaching of business communication should be based on the combination of professional business and language knowledge. Teachers are required to have solid business communication professor experience as well as students are required to have basic business English knowledge reserves. We try to realize a diversified teaching mode to support the bilingual course of business communication and provide ideas for the teaching of this course from the perspectives of real case writing and selection of film and television cases.

\section{REFERENCES}

[1] Geng C. 2017. On the Teaching Innovation of Business English Teaching: A study on Multimodal Communicative Competence of Ethnic Universities. Theory \& Practice in Language Studies, 7(4), 322.

[2] Walker C. 2011. How a corpus-based study of the factors which influence collocation can help in the teaching of business English. English for Specific Purposes, 30(2), 101-112.

[3] Tratnik A., Urh M., Jereb E. 2017. Student satisfaction with an online and a face-to-face Business English course in a higher education context. Innovations in Education \& Teaching International, 1-10.

[4] Sheehan B. 2017. Teaching in English to Non-English First Language Students in Some Thai University Programs in Business and Management. Social Science Electronic Publishing.

[5] Zhu W. 2010. Business English Teaching Mode: Its Theoretical Evolution, Features and Performance. Journal of Guangdong University of Foreign Studies.

[6] Sobkowiak P. 2018. Toward an Integrated Model of Teaching Business English in Tertiary Education.

[7] Siqi C. 2017. Integration of Three CBI Models and WeChat Mobile Learning in Business English Teaching. English Language Teaching, 10(9), 218.

[8] Sekhar G.R., Chakravorty S. 2017. English for special or specific purposes (ESP): A study on teaching ESP courses, 7(4), 112.

[9] Feng J.Y. 2018. Analysis on Mixed Teaching Mode of College Business English Based on SPOC Platform. Journal of Heilongjiang Vocational Institute of Ecological Engineering.

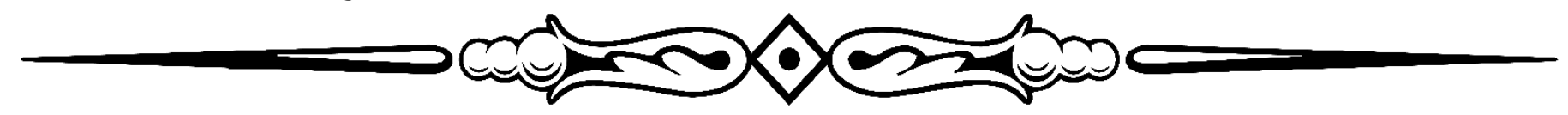

